\title{
Pharmacological treatment of pain in pregnancy
}

\section{Tratamento farmacológico da dor na gestante}

\author{
Fábio Farias de Aragão', Alexandro Ferraz Tobias²
}

DOI 10.5935/2595-0118.20190068

\section{ABSTRACT}

BACKGROUND AND OBJECTIVES: Non-obstetric causes of pain during pregnancy are very common and can be disabling if not treated properly. The objective of this study is to discuss the pharmacological treatment of pain during pregnancy with a focus on drug classification and pregnancy use, therapy options, teratogenicity, increased fetal malformations and gestational complications associated with the use of therapy.

CONTENTS: During pregnancy, the body goes through several anatomical and physiological changes. These changes can precipitate pain, which in some cases can lead to disability. In addition, pregnancy may exacerbate pre-existing painful conditions. The choice to prescribe a drug to a pregnant woman is difficult. The changes in the body of a pregnant woman influence drug absorption, distribution, metabolism, and excretion, and may alter the expected response.

CONCLUSION: The risks and benefits of the drug for the mother and the child should be considered, weighing the risks of not treating the disease adequately during pregnancy.

Keywords: Analgesic, Pain treatment, Pregnancy.

\section{RESUMO}

JUSTIFICATIVA E OBJETIVOS: As causas não obstétricas de dor durante a gravidez são muito comuns e podem ser incapacitantes se náo forem tratadas adequadamente. $\mathrm{O}$ objetivo deste estudo foi discutir o tratamento farmacológico da dor durante o período gestacional com foco na classificação de fármacos e o uso na gravidez, opçôes de terapia, teratogenicidade, aumento de malformaçóes fetais e complicaçóes gestacionais associados ao uso da terapia.

CONTEÚDO: Durante a gravidez, várias alteraçôes anatômicas e fisiológicas ocorrem no corpo. Essas alteraçóes podem precipi-

Fábio Farias de Aragão - Dhttps://orcid.org/0000-0002-8528-254X;

Alexandro Ferraz Tobias - Dhttps://orcid.org/0000-0001-7710-9547.

1. Hospital e Maternidade Natus Lumine, Clínica São Marcos, Clínica de Dor, Departamento de Anestesiologia, São Luís, MA, Brasil.

2. Hospital e Maternidade Natus Lumine, Clínica de Dor, Departamento de Anestesiologia, Sáo Luís, MA, Brasil.

Submitted on December 14, 2018.

Accepted for publication on February 28, 2019.

Conflict of interests: none - Sponsoring sources: none.

Correspondence to:

Av. Grande Oriente, 23 - Renascença

65075-180 São Luís, MA, Brasil.

E-mail: fabio.aragao30@gmail.com

(C) Sociedade Brasileira para o Estudo da Dor tar a dor, que em alguns casos pode levar à incapacidade. Além disso, a gravidez pode exacerbar condiçôes dolorosas pré-existentes. A escolha de prescrever um fármaco para uma gestante é difícil. As alteraçóes gravídicas no corpo da gestante influem na absorção, distribuição, metabolismo e excreção dos fármacos, podendo alterar a resposta esperada.

CONCLUSÁO: Deve-se considerar os riscos e benefícios do uso do fármaco para a mãe e filho, pesando-se os riscos de não tratar adequadamente a doença durante a gestação.

Descritores: Analgésicos, Gestação, Tratamento da dor.

\section{INTRODUCTION}

During pregnancy, non-obstetric causes of pain are very common and can be disabling if not properly treated. A recent study, with a cohort of over 500,000 pregnant women in the United States, found that $14 \%$ received an opioid prescription at least once during the delivery period, and 6\% received opioids throughout all quarters ${ }^{1}$.

During pregnancy, many anatomical and physiological changes take place in the body. These changes can precipitate pain, which, in some cases, can lead to disability. In addition, pregnancy can boost pre-existing painful conditions. Pain conditions during pregnancy can be bracketed in a system-based classification, such as musculoskeletal, rheumatological, neuropathic, and pelvic-abdominal pain syndromes ${ }^{2}$.

Choosing to prescribe a drug to a pregnant woman is difficult. The changes in the body of a pregnant woman influence the absorption, distribution, metabolism, and excretion of drugs, and may change the expected response. Also, it should be considered the risks and benefits for both the mother and the child when using the drug, considering the risks of not treating properly the disease during pregnancy and lactation. Risk assessment can focus not only on structural malformations (teratogenicity), but also on functional changes, changes in gestational dynamics (changes in fetal weight, abortion, prematurity, and neonatal death), and postpartum complications ${ }^{3-5}$.

The goal of this research was to discuss the pharmacological treatment of pain during pregnancy, focusing on drug classification and usage in pregnancy, therapy options, teratogenicity, increase in fetal malformations, and gestational complications associated with therapy use.

\section{CONTENTS}

Descriptive summary of available evidence on pharmacological approaches to pain management during pregnancy. It was conducted a search on the medical literature at Pubmed, Cochrane 
Library, Ovid, and Google, using the terms "pain management", "pregnancy pain", "obstetric pain”, "opioid use", "antiepileptic drug pregnancy" and "antidepressant pregnancy" in articles in English, Portuguese and Spanish, in the last 20 years or older, when relevant. The most relevant articles on the topic were selected and included in the paper.

\section{DRUG CLASSIFICATION FOR USE IN PREGNANCY}

In order to avoid the administration of drugs with potential risk and to facilitate their prescription during pregnancy, several classification systems based on animal and human data have been developed. Drug use risk classification systems in pregnant women in the United States (US Food and Drug Administration - FDA) (Table 1), the Swedish (Farmaceutiska Specialiteter i Sverige - FASS) and the Australian (Australian Drug Evaluation
Committee - ADEC) (Table 2), shared as a characteristic the categorization of drugs into letters.

The US system classifies drugs as $\mathbf{A}$ when adequate controlled studies in pregnant women showed no risk to the fetus. The Australian and Swedish systems do not use controlled studies as a prerequisite to classify a drug as $\mathbf{A}$, and they stratify category $\mathbf{B}$ (drugs used by a limited number of pregnant women) as B1, B2, and B3, based on animal data. In the Swedish classification, there is no category $\mathbf{X}$.

However, these systems have been criticized due to: a) categorization in letters is considered too simplistic and does not adequately express adverse effects on the fetus; b) the categorization in letters gives the false impression that risks increase from A to $\mathrm{X}$ and that drugs in the same category present the same risk or potential for adverse effects; c) the categories do not discriminate between potential adverse effects based on severity, incidence or

Table 1. Pharmacological risk categories in pregnancy according to the Food and Drug Administration

\begin{tabular}{ll}
\hline Categories & Interpretation \\
\hline A & Controlled studies show absent risk. \\
B & Appropriate well-controlled studies in pregnant women show no risk to the fetus. \\
& No evidence of risk in humans. \\
& Findings in animals had shown risk, but not in humans, or if adequate studies with humans have not been conducted, and \\
& the findings in animals were negative. \\
C & Risk cannot be excluded. \\
& There are no positive studies for fetal risk in humans and animals or no studies at all. However, the potential benefits justify \\
& the potential risk. \\
D & Positive evidence of risk. \\
& Data of Investigation or aftermarket release show risk to the fetus. Even though, the potential benefits may outweigh \\
& Contraindicated in pregnancy. Animal and human studies, or reports on research or aftermarket release, have shown a fetal \\
X & risk that is greater than the potential benefits.
\end{tabular}

Adapted from IV Brazilian Guidelines for Asthma Management ${ }^{6}$.

Table 2. Pharmacological risk categories in pregnancy according to the criteria of the Pharmaceutiska Specialiteter i Sverige and Australian Drug Evaluation Committee ${ }^{7}$

\begin{tabular}{|c|c|c|}
\hline Categories & Farmaceutiska Specialiteter i Sverige & Australian Drug Evaluation Committee \\
\hline$A$ & $\begin{array}{l}\text { Drugs used by many pregnant women without evidence of fetal } \\
\text { damage. }\end{array}$ & $\begin{array}{l}\text { Drugs used by many pregnant women without evidence of } \\
\text { fetal damage. }\end{array}$ \\
\hline B & $\begin{array}{l}\text { Data in humans are insufficient and limited; classification is based } \\
\text { on animal data (by allocation in one of three subgroups B1, B2 } \\
\text { or B3). }\end{array}$ & $\begin{array}{l}\text { Data in humans are insufficient and limited; classification } \\
\text { was based on animal data (by allocation in one of three sub- } \\
\text { groups B1, B2 or B3). }\end{array}$ \\
\hline B1 & $\begin{array}{l}\text { Experiments in animals did not provide evidence of an increased } \\
\text { incidence of fetal damage. }\end{array}$ & $\begin{array}{l}\text { Experiments in animals did not provide evidence of an in- } \\
\text { creased incidence of fetal damage. }\end{array}$ \\
\hline B2 & Studies in animals are insufficient. & Studies in animals are insufficient. \\
\hline B3 & $\begin{array}{l}\text { Studies in animals have shown evidence of increased incidence } \\
\text { of fetal damage, but the significance in humans is uncertain. }\end{array}$ & $\begin{array}{l}\text { Studies in animals have shown evidence of increased in- } \\
\text { cidence of fetal damage, but the significance in humans is } \\
\text { uncertain. }\end{array}$ \\
\hline C & $\begin{array}{l}\text { Drugs that, due to their pharmacological effects, have caused or } \\
\text { are suspected of having caused reproductive disorders that may } \\
\text { involve risks to the fetus, not being directly teratogenic }\end{array}$ & $\begin{array}{l}\text { Drugs that have caused or may be suspected of causing har- } \\
\text { mful effects on the human or newborn fetus without causing } \\
\text { malformations. These effects may be reversible. }\end{array}$ \\
\hline $\mathrm{D}$ & $\begin{array}{l}\text { Animal and/or human data indicate an increased incidence of fe- } \\
\text { tal malformations or other permanent damages in humans. }\end{array}$ & $\begin{array}{l}\text { The drugs have caused, are suspected of having caused, or } \\
\text { can be expected to cause an increased incidence of human } \\
\text { fetal malformations or irreversible damages. }\end{array}$ \\
\hline$x$ & Does not apply & $\begin{array}{l}\text { Drugs that have such a high risk of permanent fetal damage } \\
\text { that they must not be used during pregnancy. }\end{array}$ \\
\hline
\end{tabular}


Table 3. New Food and Drug Administration Standards for the Use of Drugs in Pregnancy, Subsection "Pregnancy" 8,9

\begin{tabular}{|c|c|}
\hline Pregnancy exposure record & $\begin{array}{l}\text { If a pregnancy exposure record is available, this subsection should contain a statement of the existence of } \\
\text { the record as well as contact information. }\end{array}$ \\
\hline Risk summary & $\begin{array}{l}\text { When drug use is contraindicated, this should be stated first. Risk statements shall be presented in the follo- } \\
\text { wing order: Based on human data, based on animal data, based on pharmacology } \\
\text { Human data are available: the risk summary should summarize the specific development of the outcome, its } \\
\text { incidence, and the effects of dose, duration of exposure, and gestational exposure time. } \\
\text { Animal data are available: labeling should summarize the findings in animals and describe the potential risk of } \\
\text { any adverse outcome in humans. Affected species, time, dose, and results should be included. } \\
\text { When the drug has a well-understood mechanism of action that may result in the adverse outcome(s) to } \\
\text { the development associated with the drug, the risk summary should explain the mechanism of action and } \\
\text { potential risks. }\end{array}$ \\
\hline Clinical considerations & $\begin{array}{l}\text { Requires titles, as relevant information is available, to: } \\
\text { - Maternal and/or embryo/fetal risk associated with the disease } \\
\text { - Dose adjustments during pregnancy and the postpartum period } \\
\text { - Maternal adverse reactions } \\
\text { - Fetal/neonatal adverse reactions } \\
\text { - Labor }\end{array}$ \\
\hline Data & $\begin{array}{l}\text { Human data: Labeling should describe adverse outcomes of development, adverse reactions, and other ad- } \\
\text { verse effects and the types of studies or reports, number of individuals and duration of each study, exposure } \\
\text { information, and limitation of data. } \\
\text {. Animal data: labeling should describe study types, animal species, dose, duration and timing of exposure, } \\
\text { presence or absence of maternal toxicity, and limitation of data. }\end{array}$ \\
\hline
\end{tabular}

type of effect; d) dose, duration, frequency, route and gestational age for drug exposure are not taken into account ${ }^{7}$.

In order to facilitate the prescribing process by providing a consistent and well-structured set of information on drug use during pregnancy and lactation, the FDA has published the Pregnancy and Lactation Labeling Rule (PLLR), on December 2014, along with Pregnancy, Lactation, and Reproductive Potential: Labeling for Human Prescription Drug and Biological Products - Content and Format. An industry-oriented document that came into force in July 2015 (Table 3) ${ }^{8,9}$. They reformulate the contents and format of the package inserts by removing references to categories A, $\mathrm{B}, \mathrm{C}, \mathrm{D}$, and $\mathrm{X}$, replacing by a summary of perinatal drug risks, discussion of relevant evidence, and a synthesis of the most relevant data to decide for the drug prescription. Essential information on pregnancy identification, contraception, and infertility is also included. The information is divided into the subsections "Pregnancy," "Lactation" and "Reproductive Potential of Men and Women"10.

On the other hand, abandoning category-based classifications requires that the professional reviews the available evidence. Thus, if the review is incomplete or the evidence is inconclusive, the risk of errors increases. Therefore, it is prudent that before prescribing a drug to pregnant or breastfeeding women, to conduct research on different platforms and measure the risks and benefits of the treatment.

\section{NON-OPIOIDS ANALGESICS}

\section{Paracetamol}

It is the most used analgesic and antipyretic during pregnancy and lactation. However, its use before birth has been associated with asthma, shorter anogenital distance in boys (predictor of low reproductive potential), autistic spectrum, neurological problems (motor development, communication), attention deficit hyperactivity disorder, behavioral changes, allergic diseases, among others. Nevertheless, studies are inconclusive, and paracetamol is considered a drug with no teratogenic effects and remains the safest analgesic during pregnancy and lactation ${ }^{11}$.

Prenatal exposure to paracetamol may be related to the consequences of women's reproductive health as a result of changes in ovarian development during intrauterine life ${ }^{12}$. Concerning maternal complications, the use of paracetamol may be related to the increased risk of developing pre-eclampsia, deep venous thrombosis, and pulmonary thromboembolism ${ }^{13}$.

As studies are inconclusive and there is extensive experience in the use of the drug during pregnancy, paracetamol remains the analgesic of choice during pregnancy, and the lowest dose should be used for the shortest possible time. Paracetamol has classification $\mathrm{B}$ by the FDA.

\section{Dipyrone}

Although this drug has been withdrawn from the market in some countries, such as the United States, because of its association with agranulocytosis and aplastic anemia, it is still being used in parts of Europe, Asia, and South American countries, such as Brazil. Its use during pregnancy is not associated with congenital malformations, intrauterine death, premature birth, or low birth weight ${ }^{14}$.

Although widely used in Brazil, two studies have shown a possible association between dipyrone use and childhood tumors: Wilms tumor and Leukemia ${ }^{15,16}$. On the other hand, in in vitro studies in animals, dipyrone showed little mutagenic or carcinogenic potential and only when administered in high doses ${ }^{17,18}$. Dipyrone is not directly related to major or minor fetal malformations, but its use should be limited to the lowest possible dose and shortest possible time ${ }^{19}$. 


\section{Acetylsalicylic acid (ASA)}

Its use was limited to its analgesic properties during pregnancy. However, the prescription in this population has been increasing in recent years. ASA does not increase the incidence of miscarriages or intrauterine death, nor does it have teratogenic effects ${ }^{20}$.

ASA has been used to treat and prevent pre-eclampsia, especially in high-risk patients, women with antiphospholipid antibody syndrome, and a history of recurrent miscarriage (associated or not with heparin), and patients who underwent to in vitro fertilization ${ }^{20}$. When used in patients at high risk for developing pre-eclampsia, ASA reduces the incidence of premature birth by $14 \%$ and restricted intrauterine growth by $20 \%$, probably because of its action by reducing placental isch$\mathrm{emia}^{21,22}$. ASA interferes with platelet function and may cause maternal or fetal bleeding ${ }^{23}$. However, when used at low doses, it has not shown a significant effect on the risk of intraventricular hemorrhage and neonatal bleeding ${ }^{24}$.

Low-dose ASA (60-150mg/day), when used in the first quarter, is not associated with an increased incidence of congenital malformations, postpartum bleeding, placental rupture, or adverse effects on anesthesia. When used in the third quarter, it was not associated with an increased incidence of intraventricular hemorrhage, neonatal hemorrhage, or premature closure of the arterial duct ${ }^{25}$.

When used at low doses, ASA is safe and has positive effects on reproduction. Low-dose aspirin has classification $\mathrm{C}$ by the FDA, but doses above $150 \mathrm{mg}$ per day are considered class D.

\section{NON-STEROIDAL ANTI-INFLAMMATORIES}

Non-steroidal anti-inflammatory drugs (NSAIDs) are among the most widely used classes of drugs during pregnancy, whether derived from propionic acid (naproxen, ibuprofen, ketoprofen), phenylacetic acid (diclofenac sodium), salicylates (acetylsalicylic acid), oxicans (meloxicam, piroxicam) or indole (indomethacin). Their mechanism of action is the inhibition of prostaglandin production by direct inhibition of the cyclooxygenase (COX) enzyme. Regarding non-selective COX inhibitors, it is not clear if there is an association between their use and the increased incidence of miscarriage when used in the first trimester or near conception ${ }^{26-28}$.

On the other hand, a study with more than 65,000 women showed that the use of NSAIDs is not an independent risk factor for abortion ${ }^{29}$. Studies in humans suggest an association between NSAIDs use and reduced female fertility, and it is prudent to avoid its use in women trying to conceive ${ }^{30}$. Regarding congenital malformations, the situation of NSAIDs is more complex. In most studies, the risk for any malformation does not increase significantly with its use but maybe increased under some conditions, notably heart defects ${ }^{31}$. On the other hand, a study that specifically assessed the risk of interventricular septal defects found no association ${ }^{32}$.

The use of NSAIDs in the third trimester of pregnancy may be associated, in the fetus, with the premature closure of the ductus arteriosus (which may lead to neonatal pulmonary hy- pertension), oligohydramnios (caused by reduced fetal urinary output), necrotizing enterocolitis and intracranial hemorrhage. In the mother, it may be related to prolonged labor period and postpartum hemorrhage ${ }^{33}$. Although short-term administration is unlikely to be associated with fetal arterial duct closure, it is common practice to avoid NSAIDs after 28 to 32 weeks until the end of pregnancy ${ }^{34}$.

Regarding selective COX-2 inhibitors, it was expected to have fewer adverse effects than non-selective ones, but the same problems are present, such as oligohydramnios and premature closure of the arterial duct ${ }^{35}$. As there are few studies on the use of this class of drugs during pregnancy, they are considered class $\mathrm{C}$ until the second trimester, and $\mathrm{D}$ in the third trimester. Non-selective anti-inflammatory have FDA classification B up to the second trimester, and classification $\mathrm{D}$ in the third ${ }^{7}$.

\section{OPIOID ANALGESICS}

Opioids are important drugs in the treatment of acute pain during pregnancy, especially when associated with NSAIDs. However, for chronic pain, the risks and benefits of its use should be discussed with the woman, and the guidelines of the American Pain Society recommend minimal use or no use if possible $^{36}$.

Opioid use during the first trimester has been associated in some studies with cardiac abnormalities, spina bifida, and gastroschisis $^{37,38}$, while others, to demonstrate these associations have failed to relate any malformations to opioid use ${ }^{39,40}$.

Opioids do not seem to have an important teratogenic effect, but there are doubts about cardiovascular defects, especially with synthetic opioids $s^{41}$.

\section{Codeine}

In a study with 67,982 pregnant women, it was observed that codeine was used in 2,666 (3.9\%) of the cases. No differences in fetal survival rate or incidence of malformations were observed between pregnant women who used or not codeine. On the other hand, its use was associated with a higher incidence of elective and emergency cesarean and postpartum hemorrhage when used at the end of pregnancy. However, these changes may be due to the underlying disease rather than drug use ${ }^{39}$. It is considered Class $\mathrm{C}$ by the FDA and Class A by ADEC.

\section{Tramadol}

In a study that evaluated $1,682,846$ pregnant women, it was observed that 1,751 used tramadol at the beginning of pregnancy, with 96 newborns presenting congenital malformation, of which 70 were severe (OR 1.33 CI 95\% 1.05-1.70). Among the malformations observed are cardiovascular defects (OR 1.56 CI 95\% 1.04-2.29) and clubfoot (OR 3.63 CI 95\% 1.61-6.89 $)^{40}$. In more advanced stages of pregnancy, it does not appear to cause major fetal effects, unless used chronically, and may lead to neonatal abstinence syndrome (NAS). There is no evidence of alterations when used during lactation ${ }^{42}$. It is considered Class $\mathrm{C}$ by the FDA and by ADEC. 


\section{Morphine}

When used in the first trimester, there are no reports of malformations and must be used with caution. During pregnancy, morphine changes its pharmacokinetics, with increased plasma clearance, shortening of half-life, decreased distribution volume, and increased formation of the 3-glucuronide metabolite. Morphine and its metabolite rapidly cross the placenta and establish maternal-fetal balance within approximately 5 minutes. Newborns exposed to shorter half-life opioids, such as morphine, are more likely to have $\mathrm{SAN}^{2,43}$. It is Class B by the FDA and C by the ADEC.

\section{Fentanyl}

The use of fentanyl during pregnancy and lactation, when used as transdermal, may be a good option for the treatment of chronic pain. In a case report of a pregnant woman who used the fentanyl patch $(125 \mu \mathrm{g} / \mathrm{h})$ throughout pregnancy, it was observed that the newborn had mild symptoms of NAS and did not require pharmacological treatment ${ }^{44}$. On the other hand, in another report of a pregnant woman who used the fentanyl patch $(100 \mu \mathrm{g} / \mathrm{h})$, the newborn had prolonged NAS, requiring oral morphine treatment until the $29^{\text {th }}$ day of life. These differences may be due to individual drug variation ${ }^{45}$. It is Class $\mathrm{C}$ by the FDA and ADEC.

\section{Methadone and buprenorphine}

Both are safe when used to treat opioid dependence during pregnancy. Prenatal exposure does not seem to alter physical, cognitive, and language development in children followed up to the 36th month of life ${ }^{46}$. It is Class $\mathrm{C}$ by the FDA and ADEC.

\section{ANTIDEPRESSANTS}

\section{Tricyclic antidepressants (TCA)}

Use during pregnancy at therapeutic doses does not appear to be associated with an increased incidence of malformations. Chronic use, or the use of high doses near delivery, may cause NAS, and the dose must be reduced between 3 and 4 weeks before delivery ${ }^{47}$. Although some studies relate the use of TCA with malformations (eye, ear, face, and digestive system) ${ }^{48}$, it is noteworthy that despite slight increases in the incidence of malformations described in some studies, most do not show any increase. Due to a large number of pregnant women who used amitriptyline without reporting toxic effects on the fetus, its use seems safe during pregnancy ${ }^{49}$. Amitriptyline is Class $\mathrm{C}$ by the FDA and ADEC; nortriptyline is Class $\mathrm{C}$ by the ADEC and $\mathrm{D}$ by the FDA.

\section{Tetracyclic antidepressants}

Maprotiline is the most studied drug, and its use is considered safe during pregnancy ${ }^{50}$. It is Class B by the FDA.

\section{Selective serotonin and norepinephrine uptake inhibitors}

One population study did not show teratogenic effects related to venlafaxine use $\mathrm{e}^{51}$. It is Class $\mathrm{C}$ by the FDA and B2 by the ADEC. In general, the use of duloxetine during pregnancy is associated with an increased incidence of miscarriage, but no malformations. Near delivery, it can lead to respiratory changes in the newborn, and during lactation, less than $1 \%$ of the drug passes to the milk, suggesting that it may be compatible with lactation. On the other hand, there are few studies to ensure its safety during pregnancy and lactation ${ }^{52}$. It is Class $\mathrm{C}$ by the FDA and $\mathrm{B} 3$ by the ADEC.

\section{MUSCLE RELAXANTS}

\section{Baclofen}

When taken orally, it is related to fetal malformations such as omphalocele. When used by intrathecal route, it seems to have no harmful effects on the fetus and has a low concentration in breast milk ${ }^{53}$. It is Class $\mathrm{B} 3$ by the ADEC.

\section{Cyclobenzaprine}

It is considered safe during pregnancy and is one of the most commonly used analgesics for the treatment of pregnancy-related low back pain. Despite a report of early closure of the ductus arteriosus, this drug is already widely used in pregnant women ${ }^{54}$. It is Class B by the FDA. During lactation, about $50 \%$ of the drug passes to breast milk.

\section{ANTICONVULSANTS}

Anticonvulsants should be used with caution during pregnancy because of the risk of major (cardiac, urogenital, central nervous system, craniofacial) and minor malformations, restricted intrauterine growth, and cognitive deficits. In addition, monotherapy and the lowest effective dose should be prioritized ${ }^{55}$.

\section{Gabapentin}

There are only a few reports of pregnant women who used gabapentin, with no evidence of increased incidence of malformations ${ }^{56}$. May be related to increased risk of fetal loss, restricted intrauterine growth, and premature birth ${ }^{57}$. It is Class $\mathrm{C}$ by the FDA and B3 by the ADEC.

\section{Pregabalin}

In a study evaluating 477 pregnant women who used pregabalin in the first trimester, RR 1.33 (CI 95\% 0.83-2.15) was found for major congenital malformations, but when used in monotherapy, RR was 1.02 (CI 95\% 0.69-1.51). Thus, when used in monotherapy, it does not seem to increase the incidence of congenital malformations ${ }^{58}$. It is Class $\mathrm{C}$ by the FDA and B3 by the ADEC.

\section{Carbamazepine}

It is associated with an increased incidence of malformations between 1 and $8.7 \%$, especially when doses above $1000 \mathrm{mg}$ per day are used $^{56}$. It is Class $\mathrm{C}$ by the FDA and B3 by the ADEC.

\section{Lamotrigine}

It does not seem to increase the incidence of malformations. When used at doses below $300 \mathrm{mg}$ per day, the incidence of mal- 
formations is about $2.0 \%$; above this dose it can reach $4.5 \%{ }^{56}$. It is Class $\mathrm{C}$ by the FDA and $\mathrm{D}$ by the ADEC.

\section{CONCLUSION}

The increased use of opioid or nonopioid analgesics by pregnant women may raise doubts about the appropriate treatment options to offer to this population. Evaluation and effective handling are limited by contraindications and risks to the fetus.

The decision to use pharmacological therapy should be based on an assessment of the risks and benefits to the mother and fetus, taking care to offer all therapeutic options to ensure the well-being of the pregnant woman, minimize fetal teratogenicity and avoid chronic symptoms and long-term disability. Understanding the most frequent painful complaints, accurate diagnosis, knowledge of the risks of analgesic for the maternal-fetal unit, and consultations with experts allow you to control unwanted symptoms and make pregnancy more enjoyable.

\section{REFERENCES}

1. Bateman BT, Hernandez-Diaz S, Rathmell JP, Seeger JD, Doherty M, Fischer MA, et al. Patterns of opioid utilization in pregnancy in a large cohort of commercial insurance beneficiaries in the United States. Anesthesiology. 2014;120(5):1216-24.

2. Shah S, Banh ET, Koury K, Bhatia G, Nandi R, Gulur P. Pain management in pregnancy: multimodal approaches. Pain Res Treat. 2015;2015:987483.

3. Public Affairs Committee of the Teratology Society. Teratology public affairs committee position paper: pregnancy labeling for prescription drugs: ten years later. Birth Defects Res A Clin Mol Teratol. 2007;79(9):627-30.

4. Addis A, Sharabi S, Bonati M. Risk classification systems for drug use during pregnancy: are they a reliable source of information? Drug Saf. 2000;23(3):245-53.

5. Schaefer C, Peters P, Miller RK. Drugs During Pregnancy and Lactation: Treatment Options and Risk Assessment. 2nd ed. London: Elsevier Academic Press; 2007.

6. IV Diretrizes Brasileiras para o Manejo da Asma. J Bras Pneumol. 2006;32(Supl 7):S447-74.

7. Wilmer E, Chai S, Kroumpouzos G. Drug safety: pregnancy rating classifications and controversies. Clin Dermatol. 2016;34(3):401-9.

8. Food and Drug Administration. Content and format of labeling for human prescription drug and biological products: requirements for pregnancy and lactation labeling. Fed Regist. 2014;79(233):72064-103.

9. Food and Drug Administration. Pregnancy, lactation, and reproductive potential: labeling for human prescription drug and biological products--content and format: guidance for industry. December 2014. Available at: www.fda.gov/downloads/Drugs/ GuidanceComplianceRegulatoryInformation/Guidances/ UCM425398.pdf

10. Rocha R, Rennó Júnior J, Ribeiro HL, Cavalsan AP, Cantilino A, Mendes-Ribeiro JA, et al. Medicamentos na gravidez e lactaçăo: novas normas do FDA. Rev Debate em Psiquiatria. 2015;28-32

11. Toda K. Is acetaminophen safe in pregnancy? Scand J Pain. 2017;17:445-6

12. Arendrup FS, Mazaud-Guittot S, Jégou B, Kristensen DM. EDC IMPACT: Is exposure during pregnancy to acetaminophen/paracetamol disrupting female reproductive development? Endocr Connect. 2018;7(1):149-58.

13. Rebordosa C, Zelop CM, Kogevinas M, Sørensen HT, Olsen J. Use of acetaminophen during pregnancy and risk of preeclampsia, hypertensive and vascular disorders: a birth cohort study. J Matern Fetal Neonatal Med. 2010;23(5):371-8.

14. da Silva Dal Pizzol T, Schüler-Faccini L, Mengue SS, Fischer MI. Dipyrone use during pregnancy and adverse perinatal events. Arch Gynecol Obstet. 2009;279(3):293-7.

15. Sharpe CR, Franco EL. Use of dipyrone during pregnancy and risk of Wilm's tumor. Epidemiology. 1996;7(5):533-5.

16. Alexander FE, Patheal SL, Biondi A, Brandalise S, Cabrera ME, Chan LC, et al. Transplacental chemical exposure and risk of infant leukemia with MLL gene fusion. Cancer Res. 2001;61(6):2542-6.

17. Izumi K, Sano N, Otsuka H, Kinouchi T, Ohnishi Y. Tumor promoting potential in male F344 rats and mutagenicity in Salmonella typhimurium of dipyrone. Carcinogenesis. 1991;12(7):1221-5.

18. Giri AK, Mukhopadhyay A. Mutagenicity assay in Salmonella and in vivo sister chromatid exchange in bone marrow cells of mice for four pyrazolone derivatives. Mutat Res. 1998;420(1-3):15-25.

19. Dathe K, Padberg S, Hultzsch S, Meixner K, Tissen-Diabaté T, Meister R, et al. Me- tamizole use during first trimester-A prospective observational cohort study on pregnancy outcome. Pharmacoepidemiol Drug Saf. 2017;26(10):1197-204

20. Bloor M, Paech M. Nonsteroidal anti-inflammatory drugs during pregnancy and the initiation of lactation. Anesth Analg. 2013;116(5):1063-75.

21. Henderson JT, Whitlock EP, O'Connor E, Senger CA, Thompson JH, Rowland MG. Low-dose aspirin for prevention of morbidity and mortality from preeclampsia: a systematic evidence review from the U.S. Preventative Services Task Force. Ann Intern Med. 2014;160(10):695-703.

22. van Vliet EO, Askie LA, Mol BW, Oudijk MA. Antiplatelet agents and the prevention of spontaneous preterm birth: a systematic review and meta-analysis. Obstet Gynecol. 2017;129(2):327-36.

23. Werler MM, Mitchell AA, Moore CA, Honein MA. Is there epidemiologic evidence to support vascular disruption as a pathogenesis of gastroschisis? Am J Med Genet A. 2009;149A(7):1399-406.

24. Askie LM, Duley L, Henderson-Smart DJ, Stewart LA; PARIS Collaborative Group. Antiplatelet agents for prevention of pre-eclampsia: a meta-analysis of individual patient data. Lancet. 2007:369(9575):1791-8

25. Mone F, Mulcahy C, McParland P, McAuliffe FM. Should we recommend universal aspirin for all pregnant women? Am J Obstet Gynecol. 2017;216(2):141.e1-141.e5.

26. Nakhai-Pour HR, Broy P, Sheehy O, Bérard A. Use of nonaspirin nonsteroidal anti-inflammatory drugs during pregnancy and the risk of spontaneous abortion. CMAJ 2011;183(15):1713-20.

27. Edwards DR, Aldridge T, Baird DD, Funk MJ, Savitz DA, Hartmann KE. Periconceptional over-the-counter nonsteroidal anti-inflammatory drug exposure and risk of spontaneous abortion. Obstet Gynecol. 2012;120(1):113-22.

28. Daniel S, Koren G, Lunenfeld E, Levy A. Immortal time bias in drug safety cohor studies: spontaneous abortion following nonsteroidal antiinflammatory drug exposure. Am J Obstet Gynecol. 2015;212(3):307.e1-6.

29. Daniel S, Koren G, Lunenfeld E, Bilenko N, Ratzon R, Levy A. Fetal exposure to nonsteroidal anti-inflammatory drugs and spontaneous abortions. CMAJ. 2014;186(5):177-82

30. Norman RJ, Wu R. The potential danger of COX-2 inhibitors. Fertil Steril 2004;81(3):493-4

31. Lind JN, Interrante JD, Ailes EC, Gilboa SM, Khan S, Frey MT, et al. Maternal use of opioids during pregnancy and congenital malformations: a systematic review. Pediatrics. 2017;139(6). Pii: e20164131.

32. Cleves MA, Savell VH Jr, Raj S, Zhao W, Correa A, Werler MM, et al. Maternal use of acetaminophen and nonsteroidal anti-inflammatory drugs (NSAIDs), and muscular ventricular septal defects. Birth Defects Res Part A Clin Mol Teratol. 2004;70(3):107-13.

33. Bloor $\mathrm{M}$, Paech $\mathrm{M}$. Nonsteroidal anti-inflammatory drugs during pregnancy and the initiation of lactation. Anesth Analg. 2013;116(5):1063-75.

34. Østensen ME, Skomsvoll JF. Anti-inflammatory pharmacotherapy during pregnancy. Expert Opin Pharmacother. 2004:5(3):571-80.

35. Sawdy RJ, Lye S, Fisk NM, Bennett PR. A double-blind randomized study of fetal side effects during and after the short-term maternal administration of indomethacin sulindac, and nimesulide for the treatment of preterm labor. Am J Obstet Gynecol. 2003;188(4):1046-51.

36. Chou R, Fanciullo GJ, Fine PG, Adler JA, Ballantyne JC, Davies P, et al. Clinical guidelines for the use of chronic opioid therapy in chronic noncancer pain. J Pain. 2009; 10(2):113-30

37. Broussard CS, Rasmussen SA, Reefhuis J, Friedman JM, Jann MW, Riehle-Colarusso T, et al. Maternal treatment with opioid analgesics and risk for birth defects. Am J Obstet Gynecol. 2011;204(4):314.e1-11.

38. Yazdy MM, Mitchell AA, Tinker SC, Parker SE, Werler MM. Periconceptional use of opioids and the risk of neural tube defects. Obstet Gynecol. 2013;122(4):838-44.

39. Nezvalová-Henriksen K, Spigset O, Nordeng H. Effects of codeine on pregnancy outcome: results from a large population-based cohort study. Eur J Clin Pharmacol. 2011;67(12):1253-61.

40. Källén B, Reis M. Use of tramadol in early pregnancy and congenital malformation risk. Reprod Toxicol. 2015;58:246-51

41. Källén B, Reis M. Ongoing pharmacological management of chronic pain in pregnancy. Drugs. 2016;76(9):915-24.

42. Bloor M, Paech MJ, Kaye R. Tramadol in pregnancy and lactation. Int J Obstet Anesth. 2012;21(2):163-7.

43. Kraychete DC, Siqueira JT, Zakka TR, Garcia JB and Specialists Group. Recommendations for the use of opioids in Brazil: Part III. Use in special situations (postoperative pain, musculoskeletal pain, neuropathic pain, gestation and lactation). Rev Dor. 2014;15(2):126-32.

44. Regan J, Chambers F, Gorman W, MacSullivan R. Neonatal abstinence syndrome due to prolonged administration of fentanyl in pregnancy. BJOG. 2000;107(4):570-2.

45. Cohen RS. Fentanyl transdermal analgesia during pregnancy and lactation. J Hum Lact. 2009;25(3):359-61.

46. Kaltenbach K, O'Grady KE, Heil SH, Salisbury AL, Coyle MG, Fischer G, et al Prenatal exposure to methadone or buprenorphine: early childhood developmental outcomes. Drug Alcohol Depend. 2018;185:40-9.

47. Lalkhen A, Grady K. Non-obstetric pain in pregnancy. Rev Pain. 2008;1(2):10-4.

48. Bérard A, Zhao JP, Sheehy O. Antidepressant use during pregnancy and the risk of major congenital malformations in a cohort of depressed pregnant women: an updated analysis of the Quebec Pregnancy Cohort. BMJ Open. 2017;7:e01337.

49. Ornoy A, Weinstein-Fudim L, Ergaz Z. Antidepressants, antipsychotics, and mood 
stabilizers in pregnancy: what do we know and how should we treat pregnant women with depression. Birth Defects Res. 2017;109(12):933-56.

50. Huybrechts KF, Hernández-Díaz S, Patorno E, Desai RJ, Mogun H, Dejene SZ, et al. Antipsychotic use in pregnancy and the risk for congenital malformations. JAMA Psychiatry. 2016;73(9):938-46.

51. Furu K, Kieler H, Haglund B, Engeland A, Selmer R, Stephansson O, et al. Selective serotonin reuptake inhibitors and venlafaxine in early pregnancy and risk of birth defects: population-based cohort study and sibling design. BMJ. 2015;17;350:h1798.

52. Andrade C. The safety of duloxetine during pregnancy and lactation. J Clin Psychiatry. 2014;75(12):e1423-7.

53. Hara T, Nakajima M, Sugano H, Karagiozov K, Hirose E, Goto K, et al. Pregnancy and breastfeeding during intrathecal baclofen therapy - case study and review. NMC Case Rep J. 2018;25;5(3):65-8
54. Moreira A, Barbin C, Martinez H, Aly A, Fonseca R. Maternal use of cyclobenzaprine (Flexeril) may induce ductal closure and persistent pulmonary hypertension in neonates. J Matern Fetal Neonatal Med. 2014;27(11):1177-9.

55. Díaz RR, Rivera AL. Manejo del dolor no obstétrico durante el embarazo. Artículo de revisión. Rev Colomb Anestesiol. 2012;40(3):213-23.

56. Weston Z, Bromley R, Jackson CF, Adab N, Clayton-Smith J, Greenhalgh J, et al. Monotherapy treatment of epilepsy in pregnancy: congenital malformation outcomes in the child. Cochrane Database Syst Rev. 2016;(11):CD010224.

57. Andrade C. Adverse pregnancy outcomes associated with gestational exposure to antiepileptic drugs. J Clin Psychiatry. 2018;31;79(4). pii: $18 f 12467$.

58. Patorno E, Bateman BT, Huybrechts KF, MacDonald SC, Cohen JM, Desai RJ, et al. Pregabalin use early in pregnancy and the risk of major congenital malformations. Neurology. 2017;23;88(21):2020-5. 